\title{
Construction of a Planar Tetrapalladium Cluster by the Reaction of Palladium(0) Bis(isocyanide) with Cyclic Tetrasilane
}

\author{
Yusuke Sunada ${ }^{1,2, *}$ (D), Nobuhiro Taniyama ${ }^{1}$, Kento Shimamoto ${ }^{2}$, Soichiro Kyushin ${ }^{3}$ (D) and \\ Hideo Nagashima 4 \\ 1 Institute of Industrial Science, The University of Tokyo, 4-6-1 Komaba Meguro-ku, Tokyo 153-8580, Japan; \\ taniyama@iis.u-tokyo.ac.jp \\ 2 Department of Applied Chemistry, School of Engineering, The University of Tokyo, \\ 4-6-1 Komaba Meguro-ku, Tokyo 153-8580, Japan; shimamo@iis.u-tokyo.ac.jp \\ 3 Division of Molecular Science, Graduate School of Science and Technology, Gunma University, \\ Kiryu, Gunma 376-8515, Japan; kyushin@gunma-u.ac.jp \\ 4 Institute for Materials Chemistry and Engineering, Kyushu University, \\ 6-1 Kasugakoen Kasuga, Fukuoka 816-8580, Japan; nagasima@cm.kyushu-u.ac.jp \\ * Correspondence: sunada@iis.u-tokyo.ac.jp; Tel.: +81-3-5452-6361
}

Received: 6 November 2017; Accepted: 22 November 2017; Published: 27 November 2017

\begin{abstract}
The planar tetrapalladium cluster $\operatorname{Pd}_{4}\left\{\mathrm{Si}\left({ }^{i} \operatorname{Pr}\right)_{2}\right\}_{3}\left(\mathrm{CN}^{t} \mathrm{Bu}\right)_{4}$ (4) was synthesised in $86 \%$ isolated yield by the reaction of palladium $(0)$ bis(isocyanide) $\operatorname{Pd}\left(\mathrm{CN}^{t} \mathrm{Bu}\right)_{2}$ with octaisopropylcyclotetrasilane (3). In the course of this reaction, the palladium atoms are clustered via insertion into the $\mathrm{Si}-\mathrm{Si}$ bonds of 3 , followed by extrusion of one $\mathrm{Si}^{i} \mathrm{Pr}_{2}$ moiety and reorganisation to afford 4 with a 54-electron configuration. The $\mathrm{CN}^{t} \mathrm{Bu}$ ligand in 4 was found to be easily replaced by $\mathrm{N}$-heterocyclic carbene $\left({ }^{i} \mathrm{Pr}_{2} \mathrm{IM}^{\mathrm{Me}}\right)$ to afford the more coordinatively unsaturated cluster $\mathrm{Pd}_{4}\left\{\mathrm{Si}\left({ }^{i} \mathrm{Pr}_{2}\right\}_{3}\left({ }^{i} \mathrm{Pr}_{2} \mathrm{IM}^{\mathrm{Me}}\right)_{3}(5)\right.$ having the planar $\mathrm{Pd}_{4} \mathrm{Si}_{3}$ core. On the other hand, the replacement of $\mathrm{CN}^{t} \mathrm{Bu}$ with a sterically compact ligand trimethylolpropane phosphite $\left\{\mathrm{P}\left(\mathrm{OCH}_{2}\right)_{3} \mathrm{CEt}\right\}$ led to a planar tripalladium cluster $\left.\mathrm{Pd}_{3}\left\{\mathrm{Si}\left({ }^{i} \mathrm{Pr}\right)_{2}\right\}_{3}\left\{\mathrm{P}_{(\mathrm{OCH}}\right)_{3} \mathrm{CEt}\right\}_{3}(6)$ and $\mathrm{Pd}\left\{\mathrm{P}\left(\mathrm{OCH}_{2}\right)_{3} \mathrm{CEt}\right\}_{4}$ in 1:1 molar ratio as products.
\end{abstract}

Keywords: palladium; cluster; cyclic organopolysilane; template; bridging silylene ligand; isocyanide

\section{Introduction}

Transition metal clusters have attracted much attention because of their unique chemical properties. These clusters have been extensively studied in homogeneous catalysis, in which the substrate can be cooperatively activated by dual metal components in the cluster [1-3]. In many cases, the clusters are also used as structural models of the active sites in heterogeneous catalysts. Detailed spectroscopic analysis of the substrates coordinated to the cluster framework has provided unique insight into the function of the active surface in, for example, the chemisorption process [4,5]. Moreover, some of the clusters provide structural and/or functional mimics of the active sites in enzymes [6-9]. A typical way to prepare the clusters is the self-assembly of metals and bridging ligands, by simply mixing the appropriate metal precursors in proper molar ratios under suitable reaction conditions. However, the self-assembly process generally forms a mixture of clusters of different nuclearities. Thus, a separation step is required to isolate the desired clusters, thereby lowering the yield of the product. In addition, the molecular structure of the formed clusters is not very predictable; in other words, this strategy is unsuitable for custom-designed clusters.

To overcome these drawbacks, a new methodology called template synthesis has recently been introduced [10-28]. In this method, the products are synthesized by clustering multiple metal atoms 
on the template. The structure of the clusters obtained in this method is highly controllable by using template molecules with appropriate structures; the yield of the product is generally high. Using this synthetic strategy, many transition metal clusters having 1D chain-like structures have been prepared by employing polyenes [10-13], multidentate phosphines [14-17], and nitrogen-containing compounds as templates [18-22]. Similarly, the use of (poly)cyclic aromatic hydrocarbons as a template led to the formation of metal clusters with 2D sheet-like structures [23-28]. However, only a limited number of 2D sheet-like clusters have been prepared, due to the lack of suitable template molecules.

We are interested in producing more 2D sheet-like clusters based on the template synthesis approach, focusing on the use of cyclic organopolysilanes as the template molecules. In our previous study, we found that a ladder polysilane, decaisopropylbicyclo[2.2.0]hexasilane (1), acts as a good template molecule for the preparation of large palladium clusters [29]. It is known that some transition metal species can be inserted into the Si-Si bonds of organosilanes [30,31], and " $\mathrm{Pd}(\mathrm{CNR})_{2}(\mathrm{CNR}=$ isocyanide $)$ " is one of the representative [32,33]. In the reaction of $\operatorname{Pd}\left(\mathrm{CN}^{t} \mathrm{Bu}\right)_{2}$ with 1, the $\mathrm{Pd}_{11}$ cluster $\operatorname{Pd}_{11}\left\{\mathrm{Si}\left({ }^{i} \mathrm{Pr}\right)\right\}_{2}\left\{\mathrm{Si}\left({ }^{i} \mathrm{Pr}\right)_{2}\right\}_{4}\left(\mathrm{CN}^{t} \mathrm{Bu}\right)_{10}$ (2), having a "folding" nanosheet structure, was confirmed to form in high isolated yield. As shown in Scheme 1, $\mathbf{1}$ behaves as a template to fix seven palladium species between seven different $\mathrm{Si}-\mathrm{Si}$ bonds. Four additional palladium species participated to form the $\mathrm{Pd}_{11}$ cluster 2 . In addition, the ligand exchange of $\mathrm{CN}^{t} \mathrm{Bu}$ in 2 to $\mathrm{CN}\left(2,4,6-\mathrm{Me}_{3}-\mathrm{C}_{6} \mathrm{H}_{2}\right)$ triggered the skeletal rearrangement to produce another $\mathrm{Pd}_{11}$ cluster to have a "folding" nanosheet structure but with a wider dihedral angle. This indicates that the structure of the cluster can be tuned by changing the auxiliary ligand on the metal. Theoretical calculations were also used to elucidate the electronic structure and bonding nature of these clusters [34].

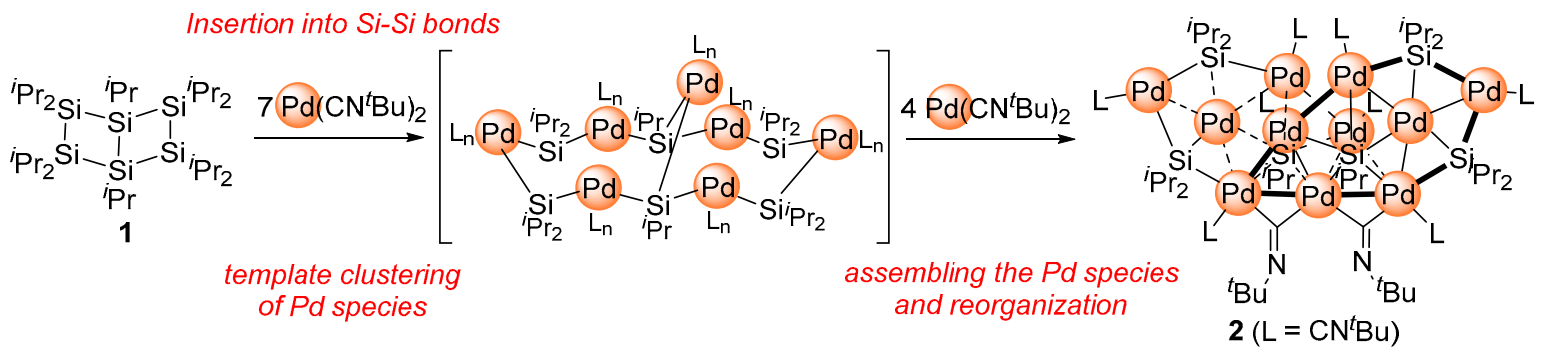

Scheme 1. Reaction of palladium(0) bis(isocyanide) $\mathrm{Pd}\left(\mathrm{CN}^{t} \mathrm{Bu}\right)_{2}$ with ladder polysilane $\mathbf{1}$ to afford the $\operatorname{Pd}_{11}$ cluster 2 .

Along the same line, in this study we intend to use octaisopropylcyclotetrasilane (3) (Chart 1) having four $\mathrm{Si}-\mathrm{Si}$ bonds as a template for the clustering of palladium species. As we expected, the reaction of 3 with $\operatorname{Pd}\left(\mathrm{CN}^{t} \mathrm{Bu}\right)_{2}$ effectively formed a planar tetrapalladium $\left(\mathrm{Pd}_{4}\right)$ cluster framework. Meanwhile, an unexpected outcome was that the reaction was accompanied by extrusion of one $\mathrm{Si}^{i} \mathrm{Pr}_{2}$ moiety, leading to the formation of a coordinatively unsaturated cluster $\mathrm{Pd}_{4}\left\{\mathrm{Si}\left({ }^{i} \mathrm{Pr}\right)_{2}\right\}_{3}\left(\mathrm{CN}^{t} \mathrm{Bu}\right)_{4}(4)$ with 54 -electron configuration as a single product. Ligand exchange of $\mathrm{CN}^{t} \mathrm{Bu}$ in 4 by an $N$-heterocyclic carbene $\left({ }^{i} \mathrm{Pr}_{2} \mathrm{IM}^{\mathrm{Me}}\right)$ proceeded with preserved $\mathrm{Pd}_{4} \mathrm{Si}_{3}$ core structure to afford a planar $\operatorname{Pd}_{4}$ cluster $\operatorname{Pd}_{4}\left\{\mathrm{Si} i\left({ }^{i} P r\right)_{2}\right\}_{3}\left({ }^{i} \operatorname{Pr}_{2} \mathrm{IM}^{\mathrm{Me}}\right)_{3}$ (5) quantitatively, which has 52 electrons and coordinatively more unsaturated than 4 . On the other hand, ligand exchange reaction of 4 with trimethylolpropane phosphite decreased the cluster nuclearity to afford the planar tripalladium cluster $\mathrm{Pd}_{3}\left\{\mathrm{Si}\left({ }^{i} \mathrm{Pr}\right)_{2}\right\}_{3}\left\{\mathrm{P}\left(\mathrm{OCH}_{2}\right)_{3} \mathrm{CEt}\right\}_{3}(6)$ and the mononuclear $\mathrm{Pd}\left\{\mathrm{P}\left(\mathrm{OCH}_{2}\right)_{3} \mathrm{CEt}\right\}_{4}$ concomitantly. 


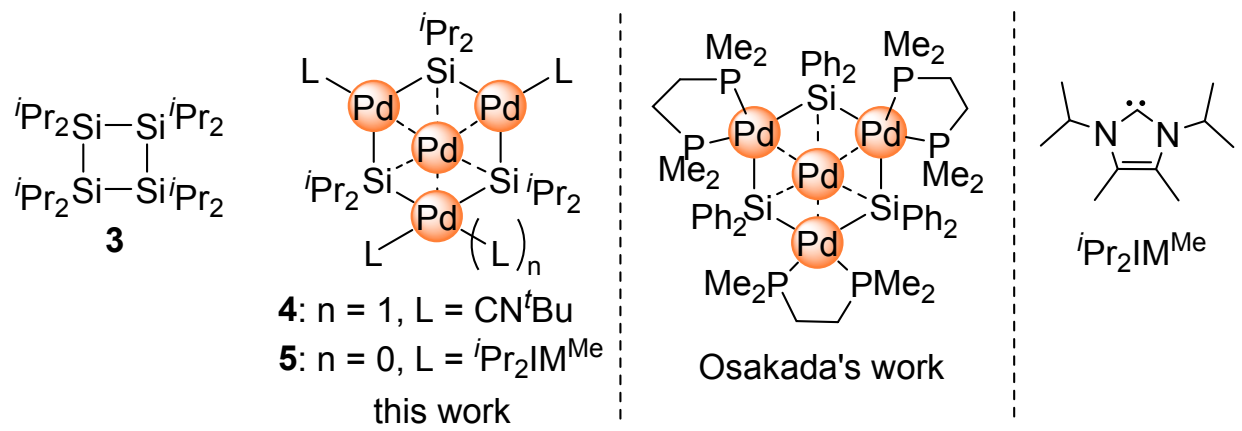

Chart 1. Structures of octaisopropylcyclotetrasilane 3, palladium clusters having bridging silylene ligands, and $N$-heterocyclic carbene ligand $\left({ }^{i} \operatorname{Pr}_{2} \mathrm{IM}^{\mathrm{Me}}\right)$.

\section{Results and Discussion}

\subsection{Synthesis of Planar $P d_{4}$ Cluster 4 by Reaction of $P d\left(C N^{t} B u\right)_{2}$ with Cyclotetrasilane 3}

As mentioned in the introduction, $\mathrm{Pd}\left(\mathrm{CN}^{t} \mathrm{Bu}\right)_{2}$ is known to show high reactivity toward insertion into the Si-Si bonds of various organosilanes. Indeed, the reaction of $\mathrm{Pd}\left(\mathrm{CN}^{t} \mathrm{Bu}\right)_{2}$ with 3 proceeded smoothly in toluene at $65{ }^{\circ} \mathrm{C}$ to afford the planar $\mathrm{Pd}_{4}$ cluster 4 in $86 \%$ isolated yield (Scheme 2). By monitoring this reaction by ${ }^{1} \mathrm{H}$ NMR spectroscopy, we found that 4 was formed as the sole product, since no other silicon-containing by-products were observed. This indicates that all the silylene $\left(\mathrm{Si}^{i} \operatorname{Pr}_{2}\right)$ moieties in 3 were incorporated into 4 . In addition, no intermediary palladium species were found in this reaction. It should be noted that Osakada et al. synthesized a structurally similar planar $\mathrm{Pd}_{4}$ cluster having three bridging silylene ligands (Chart 1$)$ by the reaction of dinuclear $\left.\left\{\mathrm{Pd}(\mathrm{PCy})_{3}\right)\right\}_{2}\left(\mu-\eta^{2}-\mathrm{SiHPh}_{2}\right)_{2}$ and 1,2-bis(dimethylphosphino)ethane (dppm) at $80^{\circ} \mathrm{C} \mathrm{[35].} \mathrm{In} \mathrm{that} \mathrm{cluster,} \mathrm{dppm} \mathrm{was} \mathrm{used} \mathrm{as} \mathrm{the}$ auxiliary ligand for the palladium centre on the edge. In contrast, two of the three palladium atoms on the edge of $4(\operatorname{Pd}(1)$ and $\operatorname{Pd}(2)$ in Figure 1) bear only one isocyanide ligand each, giving a more coordinatively unsaturated cluster with 54 cluster valence electrons, compared with that prepared by Osakada et al.

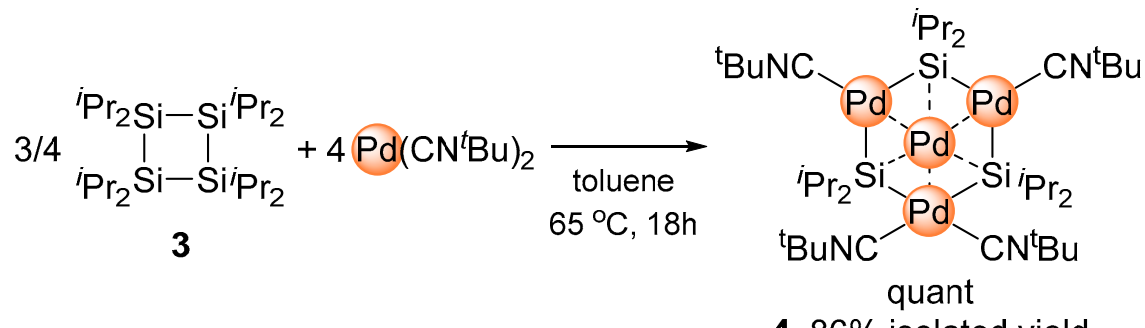

4. $86 \%$ isolated yield

Scheme 2. Reaction of octaisopropylcyclotetrasilane 3 with $\mathrm{Pd}\left(\mathrm{CN}^{t} \mathrm{Bu}\right)_{2}$ to afford 4 .

The molecular structure of 4 was determined by X-ray diffraction analysis. The ORTEP drawing of 4 is given in Figure $1 \mathrm{a}$, and the side view of its core $\mathrm{Pd}_{4} \mathrm{Si}_{3}$ fragment is shown in Figure $1 \mathrm{~b}$. The selected bond distances are summarized in Table 1. Three palladium atoms and three silicon atoms derived from the bridging silylene moieties form an almost planar six-membered ring, and the fourth palladium atom $(\operatorname{Pd}(4))$ is located at the centre of this ring. Therefore, the four palladium atoms and three silicon atoms lie on a plane, and deviations of all seven atoms from this plane are within the range of $0.028-0.178 \AA$. The $\mathrm{Pd}(4)-\mathrm{Pd}(1)-\mathrm{C}\left(\mathrm{CN}^{t} \mathrm{Bu}\right)$ and $\mathrm{Pd}(4)-\mathrm{Pd}(2)-\mathrm{C}\left(\mathrm{CN}^{t} \mathrm{Bu}\right)$ axes slightly deviate from linearity $\left(162.37(14)\right.$ and $163.14(14)^{\circ}$, respectively), which may originate from the strong trans-influence of the central $\operatorname{Pd}(4)$ atom whose formal oxidation state is $\operatorname{Pd}(0)$. The sum of the two $\mathrm{Pd}($ cent $)-\mathrm{Si}-\mathrm{C}_{\mathrm{ipso}}$ angles and the $\mathrm{C}_{\mathrm{ipso}}-\mathrm{Si}-\mathrm{C}_{\mathrm{ipso}}$ angle is close to $360^{\circ}\left(355.5^{\circ}-360.0^{\circ}\right)$. This suggests 
that the coordination geometry around the Si atoms can be regarded as pseudo-trigonal bipyramidal, and the two $\operatorname{Pd}($ edge) atoms for each $\mathrm{Si}$ atom $(\operatorname{Pd}(1)$ and $\operatorname{Pd}(2)$ for $\operatorname{Si}(1), \operatorname{Pd}(2)$ and $\operatorname{Pd}(3) \operatorname{for} \operatorname{Si}(2)$, and $\operatorname{Pd}(1)$ and $\operatorname{Pd}(3)$ for $\mathrm{Si}(3))$ are located on the axial position of the Si atom. The silylene ligand including $\mathrm{Si}(1)$ bridges over two Pd cores $(\operatorname{Pd}(1)$ and $\mathrm{Pd}(2))$. The bond distances of $\operatorname{Pd}(1)-\operatorname{Si}(1)$ and $\operatorname{Pd}(2)-S i(1)$ are 2.4252(12) and 2.4339(12) $\AA$, respectively, which are considerably shorter than those observed in other Pd(edge)-Si moieties (2.5094(11)-2.6401(12) A). In contrast, the Pd(edge)-Si(silylene) bond distances in Osakada's $\mathrm{Pd}_{4} \mathrm{Si}_{3}$ cluster are reported to be 2.505-2.546 $\AA$ with no significant deviation [35-39]. This difference may be derived from the formal electron configurations of $\operatorname{Pd}(1)$ and $\operatorname{Pd}(2)$. As suggested by our previous theoretical calculations, the metal-to-silylene charge transfer, from the occupied d-orbital of the metal to the empty p-orbital of the silylene moieties, plays a crucial role in the bonding interaction between $\mathrm{Pd}($ edge) and the bridging silylene moieties. Because $\mathrm{Pd}(3)$ has two isocyanide ligands, $\pi$-back donation from $\mathrm{Pd}$ to the two isocyanide ligands causes the $\operatorname{Pd}(3)$ centre to be more electron-deficient. This leads to longer $\operatorname{Pd}(3)$-silylene bond distances compared with those of $\operatorname{Pd}(1)-S i(1)$ and $\operatorname{Pd}(2)-S i(1)$. The $\operatorname{Pd}(3)-\operatorname{Pd}(4)$ bond length $(2.7523(5) \AA)$ is slightly longer than $\operatorname{Pd}(1)-\operatorname{Pd}(4)(2.6812(6) \AA)$ and $\operatorname{Pd}(2)-\operatorname{Pd}(4)(2.6778(6) \AA)$; however, they are within the range of metal-metal bonding interaction reported in the literature [10].

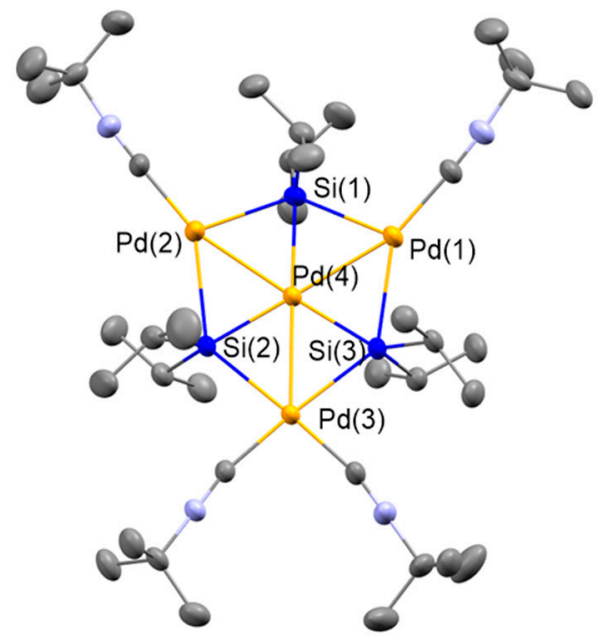

(a)

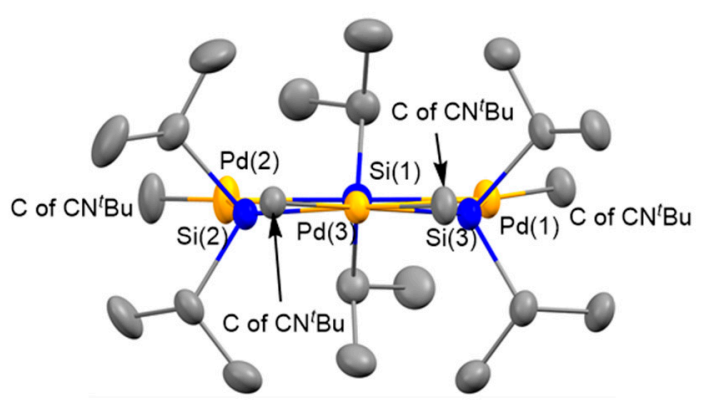

(b)

Figure 1. (a) Top view of the molecular structure of 4 with $50 \%$ probability ellipsoids. Hydrogen atoms were omitted for clarity; (b) Side view of 4 . All atoms derived from the isocyanide ligands except for the coordinated carbon atoms, and all hydrogen atoms were omitted for clarity.

Although there are three inequivalent palladium centres in the solid-state structure of 4 , only one singlet ${ }^{1} \mathrm{H}$ NMR peak derived from the ${ }^{t} \mathrm{Bu}$ moiety of the isocyanide ligand was observed at $0.99 \mathrm{ppm}$ in $\mathrm{C}_{6} \mathrm{D}_{6}$ at room temperature. In the variable temperature ${ }^{1} \mathrm{H}$ NMR spectrum of 4 in toluene- $\mathrm{d}_{8}$, this ${ }^{t} \mathrm{Bu}$ signal (appeared at $1.02 \mathrm{ppm}$ at r.t.) started to broaden at around $0{ }^{\circ} \mathrm{C}$, almost coalesced at $-70{ }^{\circ} \mathrm{C}$, then two signals appeared at 0.90 and $1.05 \mathrm{ppm}$ at $-90{ }^{\circ} \mathrm{C}$. Similarly, methyl peaks corresponding to the ${ }^{i} \mathrm{Pr}$ moieties on the $\mathrm{Si}$ atoms also began to broaden at around $0{ }^{\circ} \mathrm{C}$, then split into three slightly broad signals at $-90^{\circ} \mathrm{C}$ in an intensity ratio of ca. 1:1:1. This suggests the presence of two inequivalent isocyanide ligands, as well as three inequivalent methyl groups of the $\operatorname{Si}^{i} \mathrm{Pr}_{2}$ moieties at lower temperatures. These spectral features suggest the presence of fluxional behaviour, due to the facile site exchange of the isocyanide ligands. The fluxional behaviour of the coordinated isocyanide ligands has also been observed in the previously reported transition metal clusters [40,41]. The IR spectrum of the crystals of 4 displays two absorption bands at 2103 and $2065 \mathrm{~cm}^{-1}$ along with a shoulder band at $2125 \mathrm{~cm}^{-1}$. This spectral feature is consistent with the solid-state structure determined by X-ray diffraction analysis. Unfortunately, no signal appeared in the ${ }^{29} \mathrm{Si}\left\{{ }^{1} \mathrm{H}\right\} \mathrm{NMR}$ 
spectrum of 4 with longer $(5 \mathrm{sec})$ or shorter $(0.2 \mathrm{sec})$ relaxation time, even when using very concentrated sample with many scans.

\subsection{Ligand Exchange of $\mathbf{4}$ with $\mathrm{N}$-Heterocyclic Carbene}

In our previous paper, all $10 \mathrm{CN}^{t} \mathrm{Bu}$ ligands in 2 were found to be easily and quantitatively replaced by another isocyanide ligand $\mathrm{CN}\left(2,4,6-\mathrm{Me}_{3}-\mathrm{C}_{6} \mathrm{H}_{2}\right)$ to form a new "folding" $\mathrm{Pd}_{11}$ cluster at $-35^{\circ} \mathrm{C}$ [29]. Thus, the ligand exchange reaction of 4 with $\mathrm{CN}\left(2,4,6-\mathrm{Me}_{3}-\mathrm{C}_{6} \mathrm{H}_{2}\right)$ was attempted. However, no reaction took place even at higher temperatures. Instead, 4 underwent the facile ligand exchange with 3 equiv. of $N$-heterocyclic carbene, ${ }^{i} \operatorname{Pr}_{2} \mathrm{IM}^{\mathrm{Me}}$, to give the new planar $\mathrm{Pd}_{4} \mathrm{Si}_{3}$ cluster $\mathrm{Pd}_{4}\left\{\mathrm{Si}\left({ }^{i} \mathrm{Pr}\right)_{2}\right\}_{3}\left({ }^{i} \mathrm{Pr}_{2} \mathrm{IM}^{\mathrm{Me}}\right)_{3}(5)$ at room temperature (Scheme 3$) .{ }^{1} \mathrm{H}$ NMR monitoring of this reaction indicated that 5 was formed in quantitative yield concomitant with the formation of free isocyanide, and it was isolated in 63\% yield after purification. During this reaction, the four isocyanide ligands in 4 were replaced by three ${ }^{i} \mathrm{Pr}_{2} \mathrm{IM}^{\mathrm{Me}}$ ligands. Consequently, a more coordinatively unsaturated $\mathrm{Pd}_{4} \mathrm{Si}_{3}$ cluster with 52 valence electrons was formed. An possible alternative synthetic route for cluster 5 may be the reaction of cyclotetrasilane 3 with " $\mathrm{Pd}\left({ }^{i} \mathrm{Pr}_{2} \mathrm{IM}^{\mathrm{Me}}\right)_{2}$ ". To check this possibility, we performed the reaction of 3 with " $\mathrm{Pd}\left({ }^{i} \mathrm{Pr}_{2} \mathrm{IM}^{\mathrm{Me}}\right)_{2}$ " which was generated in situ from the reaction of $\mathrm{CpPd}\left(\eta^{3}\right.$-allyl) with 2 equiv. of ${ }^{i} \operatorname{Pr}_{2} \mathrm{IM}^{\mathrm{Me}}$. We confirmed that no reaction took place even at higher temperatures such as $65{ }^{\circ} \mathrm{C}$ in $\mathrm{C}_{6} \mathrm{D}_{6}$, suggesting that cluster 5 is available only in the reaction shown in Scheme 3.

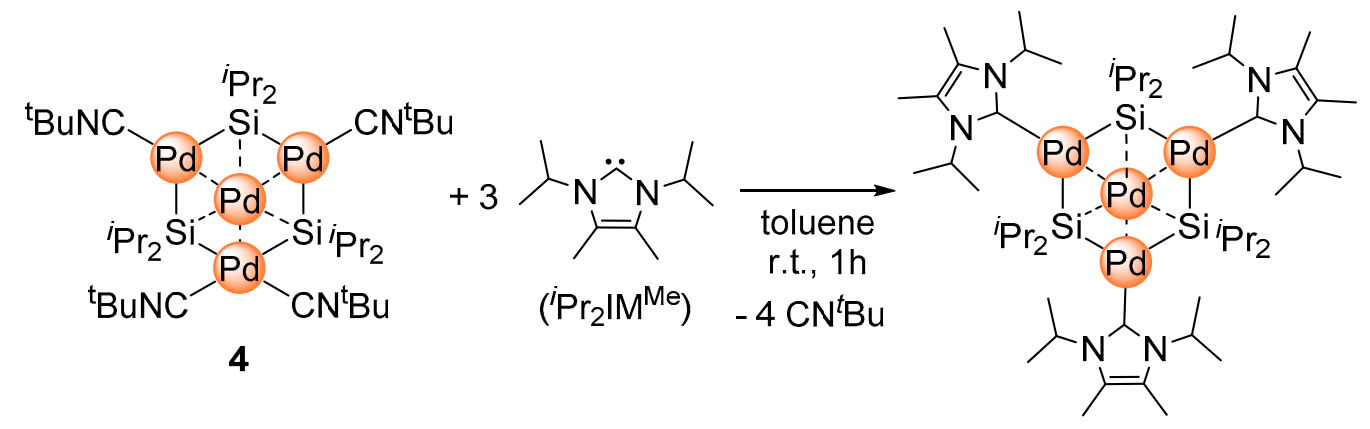

5. $63 \%$ isolated yield

Scheme 3. Synthesis of 5 via ligand exchange reaction.

The molecular structure of 5 is shown in Figure 2, and selected bond distances are summarized in Table 1. Cluster 5 has a pseudo- $C_{3}$ symmetric structure, and each Pd(edge) atom bears only one ${ }^{i} \mathrm{Pr}_{2} \mathrm{IM}{ }^{\mathrm{Me}}$ ligand. Four Pd atoms and three Si(silylene) atoms are located on a plane, and deviations of these atoms from the plane are within the range of $0.031-0.178 \AA$. As seen in cluster 4, all three $\mathrm{Pd}(4)-\mathrm{Pd}($ edge $)-\mathrm{C}\left({ }^{i} \operatorname{PrIM}{ }^{\mathrm{Me}}\right)$ axes deviate slightly from linearity $\left(\operatorname{Pd}(4)-\operatorname{Pd}(1)-\mathrm{C}\left({ }^{i} \operatorname{PrIM}{ }^{\mathrm{Me}}\right)\right.$ : 163.61(13) $\left.)^{\circ}, \operatorname{Pd}(4)-\operatorname{Pd}(2)-C\left({ }^{i} \operatorname{PrIM}{ }^{M e}\right): 170.18(12)^{\circ}, \operatorname{Pd}(4)-\operatorname{Pd}(3)-C\left({ }^{i} \operatorname{PrIM}{ }^{\mathrm{Me}}\right): 169.15(9)^{\circ}\right)$. The dihedral angle between the $\mathrm{Pd}_{4} \mathrm{Si}_{3}$ plane and the five-membered ring of the ${ }^{i} \mathrm{Pr}_{2} \mathrm{IM}^{\mathrm{Me}}$ ligands are $87.5^{\circ}-104.3^{\circ}$, suggesting the almost perpendicular orientation of the ${ }^{i} \operatorname{Pr}_{2} \mathrm{IM}^{\mathrm{Me}}$ moieties. Because cluster 5 has a pseudo- $C_{3}$ symmetric structure, the three $\operatorname{Pd}($ edge $)-\operatorname{Pd}(4)$ distances are essentially the same (2.6991(8)-2.7030(7) Å). Each silylene ligand bridges over two Pd(edge) atoms in an asymmetric manner. For instance, the bond distance of $\operatorname{Pd}(1)-\operatorname{Si}(1)(2.3668(13) \AA)$ is significantly shorter compared with that in $\operatorname{Pd}(2)-\operatorname{Si}(1)$ (2.6359(14) $\AA$ ). This may originate from the biased charge transfer from $\mathrm{Pd}$ to silylene moieties. Further studies including theoretical calculations to elucidate the details of the bonding interaction in the planar $\mathrm{Pd}_{4} \mathrm{Si}_{3}$ clusters are now underway.

The ${ }^{1} \mathrm{H}$ and ${ }^{13} \mathrm{C}\left\{{ }^{1} \mathrm{H}\right\}$ NMR spectra of 5 are consistent with the expectation from its pseudo- $C_{3}$ symmetric structure. One singlet derived from the carbene carbon atom of the ${ }^{i} \operatorname{Pr}_{2} \mathrm{IM}^{\mathrm{Me}}$ moiety was observed at $194.0 \mathrm{ppm}$ in the ${ }^{13} \mathrm{C}\left\{{ }^{1} \mathrm{H}\right\}$ NMR spectrum. The ${ }^{29} \mathrm{Si}\left\{{ }^{1} \mathrm{H}\right\}$ NMR spectrum of 4 showed a singlet at 223.1 ppm, which is comparable to those derived from the silylene moieties of 2 (191.85 and 
$226.63 \mathrm{ppm}$ ). This signal appeared at slightly lower field compared with Osakada's $\mathrm{Pd}_{4} \mathrm{Si}_{3}$ cluster (195 ppm) [35], but it is within the range for bridging silylene ligands reported in the literature [42-44].

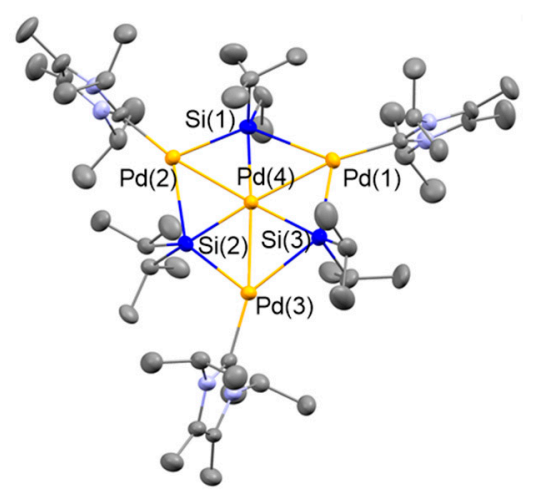

(a)

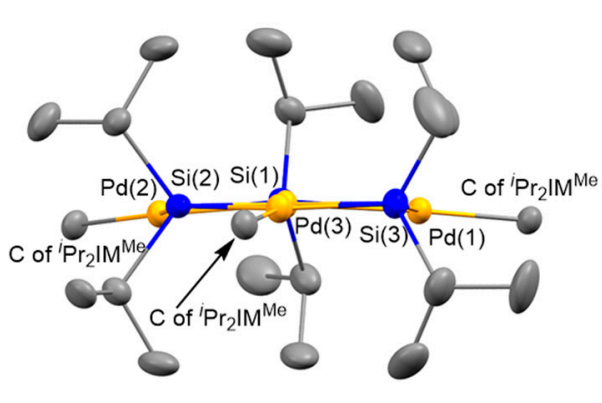

(b)

Figure 2. (a) Top view of the molecular structure of 5 with $50 \%$ probability ellipsoids. Hydrogen atoms were omitted for clarity; (b) Side view of 5 . All atoms derived from the ${ }^{i} \mathrm{Pr}_{2} \mathrm{IMMe}$ ligands except for the coordinated carbon atoms, and all hydrogen atoms were omitted for clarity.

\subsection{Ligand Exchange of $\mathbf{4}$ with Trimethylolpropane Phosphite to Afford the Planar Pd $d_{3}$ Cluster 6}

The facile ligand exchange of 4 with ${ }^{i} \operatorname{Pr}_{2} \mathrm{IM}^{\mathrm{Me}}$ prompted us to examine the reaction of 4 with trimethylolpropane phosphite. This reaction was first monitored by ${ }^{31} \mathrm{P}\left\{{ }^{1} \mathrm{H}\right\} \mathrm{NMR}$. Treating 4 with 7 equiv. of trimethylolpropane phosphite provides two signals at 118.9 and $143.9 \mathrm{ppm}$. The former was assignable to the mononuclear $\mathrm{Pd}\left\{\mathrm{P}\left(\mathrm{OCH}_{2}\right)_{3} \mathrm{CEt}\right\}_{4}$ complex by comparison with the independently prepared $\mathrm{Pd}\left\{\mathrm{P}\left(\mathrm{OCH}_{2}\right)_{3} \mathrm{CEt}\right\}_{4}$ from the reaction of $\mathrm{CpPd}\left(\eta^{3}\right.$-allyl) with 4 equiv. of $\mathrm{P}\left(\mathrm{OCH}_{2}\right)_{3} \mathrm{CEt}$. With a lower amount of $\mathrm{P}\left(\mathrm{OCH}_{2}\right)_{3} \mathrm{CEt}$, no intermediary species were visible in the reaction of 4 to form $\mathbf{6}$ and $\mathrm{Pd}\left\{\mathrm{P}\left(\mathrm{OCH}_{2}\right)_{3} \mathrm{CEt}\right\}_{4}$. For example, treating 4 with 4 equiv. of $\mathrm{P}\left(\mathrm{OCH}_{2}\right)_{3} \mathrm{CEt}$ resulted in the exclusive formation of 6 and $\mathrm{Pd}\left\{\mathrm{P}\left(\mathrm{OCH}_{2}\right)_{3} \mathrm{CEt}\right\}_{4}$ with recovery of 4 . Because $\mathrm{Pd}\left\{\mathrm{P}\left(\mathrm{OCH}_{2}\right)_{3} \mathrm{CEt}\right\}_{4}$ shows low solubility in diethyl ether or pentane, it can be easily removed from the crude product. Subsequent recrystallisation from pentane gave the planar tripalladium cluster 6 in a pure form. During this reaction, the sterically compact phosphite ligand may first attack the central palladium atom in 4 , followed by the fragmentation to afford 6 and $\mathrm{Pd}\left\{\mathrm{P}\left(\mathrm{OCH}_{2}\right)_{3} \mathrm{CEt}\right\}_{4}$ as products in 1:1 molar ratio (Scheme 4). It should be noted that the synthesis of structurally similar triplatinum clusters bearing bridging silylene ligands has been reported [45-48]. However, to the best of our knowledge, cluster 6 is the first example of the palladium analogue of these clusters.

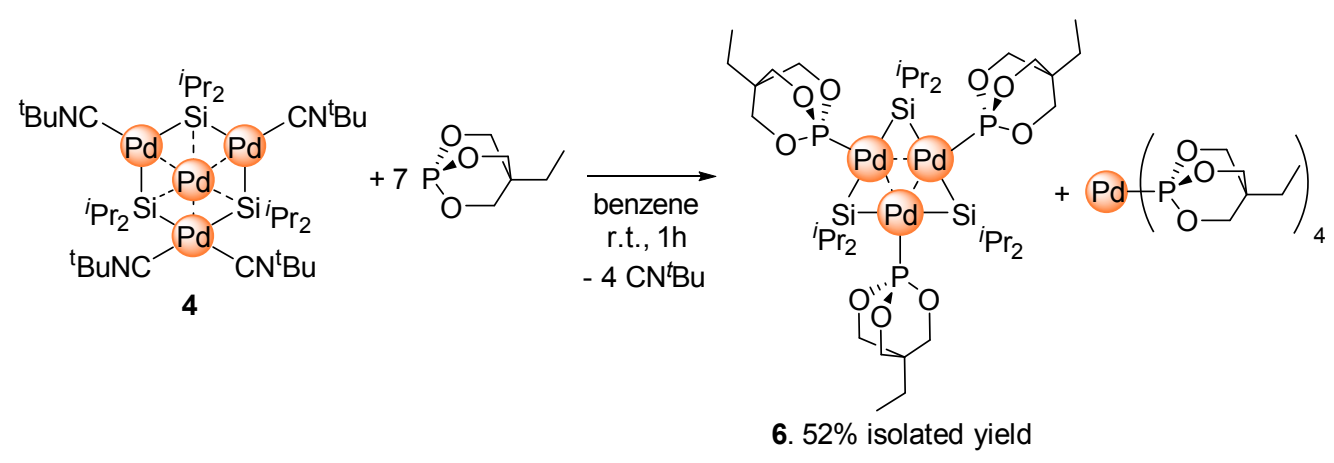

Scheme 4. Ligand exchange of 4 with trimethylolpropanephosphite to give the planar tripalladium cluster 6 . 
The molecular structure of $\mathbf{6}$ was confirmed by X-ray diffraction analysis. The ORTEP drawing is shown in Figure 3, and the selected bond distances are depicted in Table 1. Cluster 6 can be regarded formally as a 42-electron cluster with three $\mathrm{Pd}-\mathrm{Pd}$ bonds similar to those found in the previously reported trinuclear $\mathrm{Pt}_{3} \mathrm{Si}_{3}$ clusters [45-48]. As shown in Figure $3 \mathrm{~b}$, there is a planar $\mathrm{Pd}_{3} \mathrm{Si}_{3}$ unit, and the deviations of all atoms from the plane are within the range of $0.000-0.172 \AA$. One of the three phosphorus atoms (P(3) in Figure $3 b)$ is located below the plane by $0.504 \AA$. The Pd-Pd bond distances are 2.7041(6)-2.7117(5) $\AA$, which are almost comparable to those found in 5 and reported polynuclear palladium clusters [10]. In contrast to clusters 4 and 5, the silylene ligands symmetrically bridge over two palladium atoms, and the $\mathrm{Pd}-\mathrm{Si}$ bond lengths are 2.3557(9)-2.3754(11) $\AA$, which are in the normal range for those found in palladium complexes having bridging silylene ligands.

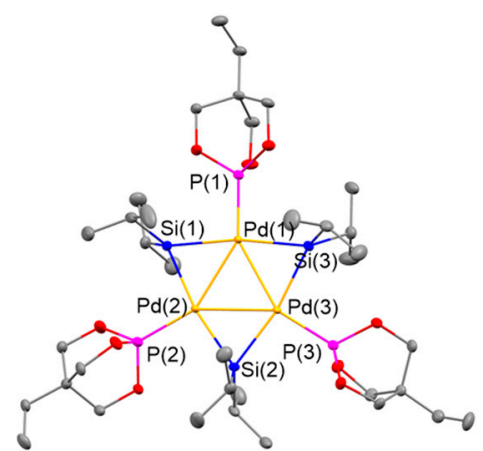

(a)

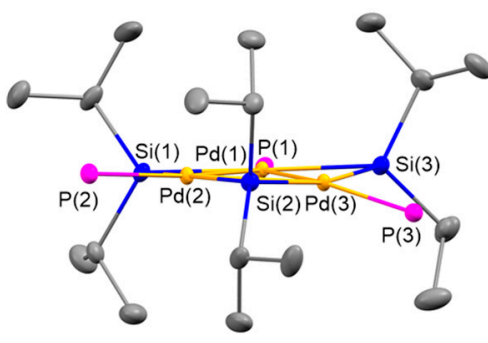

(b)

Figure 3. (a) Top view of the molecular structure of 6 with $50 \%$ probability ellipsoids. Hydrogen atoms were omitted for clarity; (b) Side view of $\mathbf{6}$. All atoms derived from the phosphite ligands except for the coordinated phosphorus atoms, and all hydrogen atoms were omitted for clarity.

Table 1. Selected bond distances for 4, 5 and 6 .

\begin{tabular}{lccc}
\hline & $\mathbf{4}$ & $\mathbf{5}$ & $\mathbf{6}$ \\
\hline $\operatorname{Pd}(1)-\operatorname{Pd}(4)$ & $2.6812(6)$ & $2.7029(6)$ & - \\
$\operatorname{Pd}(2)-\operatorname{Pd}(4)$ & $2.6778(6)$ & $2.6991(8)$ & - \\
$\operatorname{Pd}(3)-\operatorname{Pd}(4)$ & $2.7523(5)$ & $2.7030(7)$ & - \\
$\operatorname{Pd}(1)-\operatorname{Pd}(2)$ & - & - & $2.7117(5)$ \\
$\operatorname{Pd}(1)-\operatorname{Pd}(3)$ & - & - & $2.7041(6)$ \\
$\operatorname{Pd}(2)-\operatorname{Pd}(3)$ & - & - & $2.7050(4)$ \\
$\operatorname{Pd}(1)-\operatorname{Si}(1)$ & $2.4252(12)$ & $2.3668(13)$ & $2.3557(9)$ \\
$\operatorname{Pd}(1)-\operatorname{Si}(3)$ & $2.5827(12)$ & $2.6359(14)$ & $2.3602(9)$ \\
$\operatorname{Pd}(2)-S i(1)$ & $2.4339(12)$ & $2.6518(12)$ & $2.3707(12)$ \\
$\operatorname{Pd}(2)-\operatorname{Si}(2)$ & $2.6401(12)$ & $2.3769(15)$ & $2.3754(11)$ \\
$\operatorname{Pd}(3)-S i(2)$ & $2.5094(11)$ & $2.6659(14)$ & $2.3658(11)$ \\
$\operatorname{Pd}(3)-S i(3)$ & $2.5341(12)$ & $2.3693(12)$ & $2.3691(11)$ \\
$\operatorname{Pd}(4)-S i(1)$ & $2.3106(12)$ & $2.2638(14)$ & - \\
$\operatorname{Pd}(4)-\operatorname{Si}(2)$ & $2.2621(10)$ & $2.2558(11)$ & - \\
$\operatorname{Pd}(4)-\operatorname{Si}(3)$ & $2.2692(12)$ & $2.2603(13)$ & - \\
\hline
\end{tabular}

The NMR spectra of $\mathbf{6}$ are consistent with those expected from the molecular structure determined by X-ray diffraction analysis. For instance, the methyl and methine groups of the ${ }^{i} \mathrm{Pr}$ groups appeared at 1.86 and $1.93 \mathrm{ppm}$ as doublet and septet, respectively. The ${ }^{31} \mathrm{P}\left\{{ }^{1} \mathrm{H}\right\} \mathrm{NMR}$ spectrum of 6 exhibited an intense singlet at $143.9 \mathrm{ppm}$.

\section{Materials and Methods}

Manipulation of air and moisture sensitive compounds was carried out under a dry nitrogen atmosphere, using standard Schlenk tube techniques associated with a high-vacuum line, or 
in the glove box filled with dry nitrogen. All solvents were distilled over appropriate drying reagents prior to use (toluene, benzene, ether, pentane, hexamethyldisiloxane (HMDSO); $\mathrm{Ph}_{2} \mathrm{CO} / \mathrm{Na}$ ). ${ }^{1} \mathrm{H},{ }^{13} \mathrm{C}\left\{{ }^{1} \mathrm{H}\right\},{ }^{29} \mathrm{Si}\left\{{ }^{1} \mathrm{H}\right\}$ and ${ }^{31} \mathrm{P}\left\{{ }^{1} \mathrm{H}\right\}$ NMR spectra were recorded on a Lambda 400 spectrometer at ambient temperature unless otherwise noted. ${ }^{1} \mathrm{H},{ }^{13} \mathrm{C}\left\{{ }^{1} \mathrm{H}\right\},{ }^{29} \mathrm{Si}\left\{{ }^{1} \mathrm{H}\right\}$ and ${ }^{31} \mathrm{P}\left\{{ }^{1} \mathrm{H}\right\}$ NMR chemical shifts ( $\delta$ values) were given in ppm relative to the solvent signal or standard resonances $\left({ }^{29} \mathrm{Si}\left\{{ }^{1} \mathrm{H}\right\}\right.$ : external tetramethylsilane, ${ }^{31} \mathrm{P}\left\{{ }^{1} \mathrm{H}\right\}$ : external $\left.\mathrm{H}_{3} \mathrm{PO}_{4}\right)$. Elemental analyses were performed at the A Rabbit Science Co., Ltd. (Ayako Sato, 5-4-21 Nishihashimoto, Midori, Sagamihara, Kanagawa 252-0131, Japan). IR spectra were recorded on a PerkinElmer Spectrum Two spectrometer. Starting materials, octaisopropylcyclotetrasilane (3) [49], $\mathrm{Pd}\left(\mathrm{CN}^{\mathrm{t} B u}\right)_{2}$ [31], $\mathrm{CpPd}\left(\eta^{3}\right.$-allyl) and ${ }^{i} \mathrm{Pr}_{2} \mathrm{IM}^{\mathrm{Me}}$ [50] were synthesized by the method reported in the literature.

\subsection{Synthesis of $P d_{4}\left(S i\left({ }^{i} \mathrm{Pr}\right)_{2}\right)_{3}\left(C N^{t} B u\right)_{4}(4)$}

In a $50-\mathrm{mL}$ Schlenk tube, $\mathrm{Pd}\left(\mathrm{CN}^{t} \mathrm{Bu}\right)_{2}(273 \mathrm{mg}, 1.00 \mathrm{mmol})$ was dissolved in toluene $(20 \mathrm{~mL})$, then octaisopropylcyclotetrasilane (3) $(86 \mathrm{mg}, 0.19 \mathrm{mmol})$ was added to this solution at room temperature. The solution was stirred at $65^{\circ} \mathrm{C}$ for $18 \mathrm{~h}$, then the solvent was removed in vacuo. The remaining crude product was dissolved in pentane $(40 \mathrm{~mL})$, and centrifuged to remove the insoluble materials. The supernatant was collected, concentrated to ca. $5 \mathrm{~mL}$, and cooled at $-35^{\circ} \mathrm{C}$ to give 4 as yellow crystals $(237 \mathrm{mg}, 0.22 \mathrm{mmol}, 86 \%) .{ }^{1} \mathrm{H} \mathrm{NMR}\left(400 \mathrm{MHz}\right.$, r.t., $\left.\mathrm{C}_{6} \mathrm{D}_{6}\right): \delta=0.99\left(\mathrm{~s}, 36 \mathrm{H},{ }^{t} \mathrm{Bu}\right)$, $\left.1.85\left(\mathrm{~d}, J=7.3 \mathrm{~Hz}, 36 \mathrm{H}, \mathrm{CH}\left(\mathrm{CH}_{3}\right)_{2}\right), 2.42\left(\mathrm{sept}, J=7.3 \mathrm{~Hz}, 6 \mathrm{H}, \mathrm{CH}\left(\mathrm{CH}_{3}\right)_{2}\right) .{ }^{13} \mathrm{C}_{1}{ }^{1} \mathrm{H}\right\} \mathrm{NMR}(100 \mathrm{MHz}$, r.t., $\left.\mathrm{C}_{6} \mathrm{D}_{6}\right): \delta=23.8\left(\mathrm{~s}, \mathrm{Si}\left\{\mathrm{CH}\left(\mathrm{CH}_{3}\right)_{2}\right\}_{2}\right), 26.3\left(\mathrm{~s}, \mathrm{C}\left(\mathrm{CH}_{3}\right)_{3}\right), 30.1$ (s, $\left.\mathrm{Si}\left\{\mathrm{CH}\left(\mathrm{CH}_{3}\right)_{2}\right\}_{2}\right), 53.1\left(\mathrm{~s}, \mathrm{C}\left(\mathrm{CH}_{3}\right)_{3}\right)$ (one peak due to the $\underline{C} \mathrm{~N}^{t} \mathrm{Bu}$ moiety was not detectable). ${ }^{29} \mathrm{Si}\left\{{ }^{1} \mathrm{H}\right\} \mathrm{NMR}\left(119 \mathrm{MHz}\right.$, r.t., $\left.\mathrm{C}_{6} \mathrm{D}_{6}\right)$ : no signal appeared. IR (ATR): $v_{\mathrm{CN}}=2125,2103,2065 \mathrm{~cm}^{-1}$. Anal calcd for $\mathrm{C}_{38} \mathrm{H}_{78} \mathrm{~N}_{4} \mathrm{Pd}_{4} \mathrm{Si}_{3} ; \mathrm{C} 41.45, \mathrm{H}$ 7.14, N 5.09; found: C 41.17, H 6.84, N 5.20.

\subsection{Synthesis of $\left.\mathrm{Pd}_{4}\left(\mathrm{Si}^{\mathrm{i}}{ }^{\mathrm{P}} \mathrm{Pr}\right)_{2}\right)_{3}\left({ }^{i} \mathrm{Pr}_{2} \mathrm{IM}^{\mathrm{Me}}\right)_{4}$ (5)}

In a 20-mL Schlenk tube, $4(67 \mathrm{mg}, 0.061 \mathrm{mmol})$ was dissolved in toluene $(20 \mathrm{~mL})$, then ${ }^{i} \mathrm{Pr}_{2} \mathrm{IM}^{\mathrm{Me}}$ (33 $\mathrm{mg}, 0.183 \mathrm{mmol}$ ) was added to this solution at room temperature. The solution was stirred at room temperature for $1 \mathrm{~h}$, then the solvent was removed in vacuo. The remaining solid was again dissolved in toluene $(20 \mathrm{~mL})$, stirred at room temperature for $1 \mathrm{~h}$, then the solvent was removed in vacuo. The remaining crude product was extracted with pentane $(10 \mathrm{~mL})$, and the mother liquid was centrifuged to remove the small amount of insoluble materials. The supernatant was collected, then the solvent was removed in vacuo. The remaining powder was washed with HMDSO $(5 \mathrm{~mL} \times 2)$ to afford 5 as a brown powder $(50 \mathrm{mg}, 0.038 \mathrm{mmol}, 63 \%)$. Crystals suitable for X-ray diffraction analysis were obtained by cooling the saturated pentane solution at $-35^{\circ} \mathrm{C}$. ${ }^{1} \mathrm{H} \mathrm{NMR}\left(400 \mathrm{MHz}\right.$, r.t., $\left.\mathrm{C}_{6} \mathrm{D}_{6}\right): \delta=1.44$ $\left(\mathrm{d}, J=7.3 \mathrm{~Hz}, 36 \mathrm{H}, \mathrm{CH}\left(\mathrm{CH}_{3}\right)_{2}\right), 1.69(\mathrm{~s}, 18 \mathrm{H}, \mathrm{C}=\mathrm{CMe}), 1.85\left(\mathrm{~d}, J=7.3 \mathrm{~Hz}, 36 \mathrm{H}, \mathrm{CH}\left(\mathrm{CH}_{3}\right)_{2}\right), 2.10$ (sept, $\left.J=7.3 \mathrm{~Hz}, 6 \mathrm{H}, \mathrm{Si}\left\{\mathrm{CH}\left(\mathrm{CH}_{3}\right)_{2}\right\}_{2}\right), 6.24$ (sept, $\left.J=7.3 \mathrm{~Hz}, 6 \mathrm{H}, \mathrm{N}\left\{\mathrm{CH}\left(\mathrm{CH}_{3}\right)_{2}\right\}\right) .{ }^{13} \mathrm{C}\left\{{ }^{1} \mathrm{H}\right\} \mathrm{NMR}(100 \mathrm{MHz}$, r.t., $\left.\mathrm{C}_{6} \mathrm{D}_{6}\right): \delta=10.2\left(\mathrm{~s}, \mathrm{Si}\left\{\mathrm{CH}\left(\mathrm{CH}_{3}\right)_{2}\right\}_{2}\right), 22.5\left(\mathrm{~s}, \mathrm{Si}\left\{\mathrm{CH}\left(\mathrm{CH}_{3}\right)_{2}\right\}_{2}\right), 23.2\left(\mathrm{~s}, \mathrm{~N}\left\{\mathrm{CH}\left(\mathrm{CH}_{3}\right)_{2}\right\}\right), 23.6(\mathrm{~s}, \mathrm{C}=\mathrm{CMe})$, $54.0\left(\mathrm{~s}, \mathrm{~N}\left\{\mathrm{CH}\left(\mathrm{CH}_{3}\right)_{2}\right\}\right), 122.6(\mathrm{~s}, \mathrm{C}=\mathrm{CMe}), 194.0(\mathrm{~s}, \mathrm{Pd}-\mathrm{C}) .{ }^{29} \mathrm{Si}\left\{{ }^{1} \mathrm{H}\right\} \mathrm{NMR}\left(119 \mathrm{MHz}\right.$, r.t., $\left.\mathrm{C}_{6} \mathrm{D}_{6}\right): \delta=243.3$ (s, $\mathrm{SiMe}_{2}$ ). Anal calcd for $\mathrm{C}_{51} \mathrm{H}_{102} \mathrm{~N}_{6} \mathrm{Pd}_{4} \mathrm{Si}_{3} ; \mathrm{C} 46.78, \mathrm{H}$ 7.85, N 6.42; found: C 46.75, H 7.74, N 6.25.

\subsection{Synthesis of $\left.\mathrm{Pd}_{3}\left\{\mathrm{Si}^{i}{ }^{\mathrm{P} r}\right)_{2}\right\}_{3}\left\{\mathrm{P}\left(\mathrm{OCH}_{2}\right)_{3} \mathrm{CEt}\right\}_{3}$ (6)}

In a 20-mL Schlenk tube, $4(30 \mathrm{mg}, 0.027 \mathrm{mmol})$ was dissolved in benzene $(20 \mathrm{~mL})$, then trimethylolpropane phosphite $(31 \mathrm{mg}, 0.19 \mathrm{mmol})$ was added to this solution at room temperature. The solution was stirred at room temperature for $1 \mathrm{~h}$. After freeze-drying, the remaining solid was dissolved in ether $(20 \mathrm{~mL})$, and centrifuged to remove the insoluble materials. The supernatant was collected, then the solvent was removed in vacuo. The remaining powder was washed with HMDSO ( $5 \mathrm{~mL}$ ) and cold pentane ( $3 \mathrm{~mL}$ ) to afford 6 as a brown powder (16 mg, $0.014 \mathrm{mmol}, 52 \%)$. Crystals suitable for X-ray diffraction analysis were obtained by cooling the saturated ether solution at $-35{ }^{\circ} \mathrm{C}$. ${ }^{1} \mathrm{H}$ NMR $\left(400 \mathrm{MHz}\right.$, r.t., $\left.\mathrm{C}_{6} \mathrm{D}_{6}\right): \delta=0.06\left(\mathrm{t}, J=7.6 \mathrm{~Hz}, 9 \mathrm{H}, \mathrm{CH}_{2} \mathrm{CH}_{3}\right), 0.19\left(\mathrm{q}, J=7.6 \mathrm{~Hz}, 6 \mathrm{H}, \mathrm{CH}_{2} \mathrm{CH}_{3}\right)$, $1.86\left(\mathrm{~d}, J=7.6 \mathrm{~Hz}, 36 \mathrm{H}, \mathrm{CH}\left(\mathrm{CH}_{3}\right)_{2}\right), 1.93\left(\mathrm{sept}, J=7.6 \mathrm{~Hz}, 6 \mathrm{H}, \mathrm{Si}\left\{\mathrm{CH}\left(\mathrm{CH}_{3}\right)_{2}\right\}_{2}\right), 3.56\left(\mathrm{~s}, 18 \mathrm{H}, \mathrm{OCH}_{2}-\right)$. 
${ }^{13} \mathrm{C}\left\{{ }^{1} \mathrm{H}\right\} \mathrm{NMR}\left(100 \mathrm{MHz}\right.$, r.t., $\left.\mathrm{C}_{6} \mathrm{D}_{6}\right): \delta=6.7\left(\mathrm{~s}, \mathrm{CH}_{2} \mathrm{CH}_{3}\right), 21.3\left(\mathrm{~s}, \mathrm{Si}\left\{\mathrm{CH}\left(\mathrm{CH}_{3}\right)_{2}\right\}_{2}\right), 23.6\left(\mathrm{~s}, \mathrm{CH}_{2} \mathrm{CH}_{3}\right)$, $29.6\left(\mathrm{~s}, \mathrm{Si}\left\{\mathrm{CH}\left(\mathrm{CH}_{3}\right)_{2}\right\}_{2}\right), 34.1\left(\mathrm{dd}, J=11.5,22.0 \mathrm{~Hz}, \mathrm{CCH}_{2} \mathrm{CH}_{3}\right), 72.4\left(\mathrm{~s}, \mathrm{OCH}_{2}\right) .{ }^{29} \mathrm{Si}\left\{{ }^{1} \mathrm{H}\right\} \mathrm{NMR}(119 \mathrm{MHz}$, r.t., $\left.\mathrm{C}_{6} \mathrm{D}_{6}\right)$; no signal appeared. ${ }^{31} \mathrm{P}$ NMR $\left(162 \mathrm{MHz}\right.$, r.t., $\left.\mathrm{C}_{6} \mathrm{D}_{6}\right)$ : $\delta=143.9$. Even though a number of attempts have been made, we have been unable to obtain satisfactory elemental analysis values for $\mathbf{6}$, presumably due to the high instability toward both air and moisture. Anal calcd for $\mathrm{C}_{36} \mathrm{H}_{75} \mathrm{O}_{9} \mathrm{P}_{3} \mathrm{Pd}_{3} \mathrm{Si}_{3}$; C 37.65, H 6.58; found: C 38.40, H 5.83.

\subsection{In Situ Preparation of $P d\left\{P\left(\mathrm{OCH}_{2}\right)_{3} \mathrm{CEt}\right\}_{4}$}

In a J. Young NMR tube, $\mathrm{CpPd}\left(\eta^{3}\right.$-allyl $)(20 \mathrm{mg}, 0.094 \mathrm{mmol})$ was dissolved in $\mathrm{C}_{6} \mathrm{D}_{6}(0.5 \mathrm{~mL})$, then trimethylolpropane phosphite $(61 \mathrm{mg}, 0.38 \mathrm{mmol})$ was added to this solution at room temperature. The solution was allowed to stand at room temperature for $45 \mathrm{~min} .{ }^{1} \mathrm{H}$ and ${ }^{31} \mathrm{P}\left\{{ }^{1} \mathrm{H}\right\} \mathrm{NMR}$ spectra indicates quantitative formation of $\mathrm{Pd}\left\{\mathrm{P}\left(\mathrm{OCH}_{2}\right)_{3} \mathrm{CEt}\right\}_{4} .{ }^{1} \mathrm{H} \mathrm{NMR}\left(400 \mathrm{MHz}\right.$, r.t., $\left.\mathrm{C}_{6} \mathrm{D}_{6}\right): \delta=0.03$ $\left(\mathrm{t}, J=7.6 \mathrm{~Hz}, 12 \mathrm{H}, \mathrm{CH}_{2} \mathrm{CH}_{3}\right), 0.14\left(\mathrm{q}, 6 \mathrm{H}, J=7.6 \mathrm{~Hz}, 8 \mathrm{H}, \mathrm{CH}_{2} \mathrm{CH}_{3}\right), 3.65\left(\mathrm{~s}, 24 \mathrm{H}, \mathrm{OCH}_{2}-\right) .{ }^{31} \mathrm{P}\left\{{ }^{1} \mathrm{H}\right\} \mathrm{NMR}$ $\left(162 \mathrm{MHz}\right.$, r.t., $\left.\mathrm{C}_{6} \mathrm{D}_{6}\right): \delta=118.9$.

\subsection{X-Ray Data Collection and Reduction}

X-ray crystallography for complex $\mathbf{4}$ and $\mathbf{5}$ was performed on a Rigaku Saturn CCD area

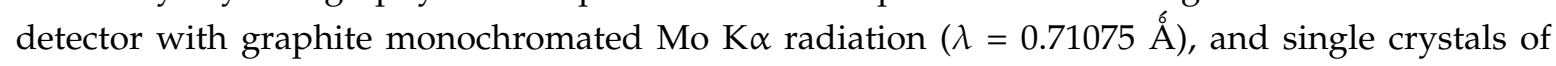
6 suitable for X-ray crystallography were analyzed by synchrotron radiation at beam line BL02B1 ( $\lambda=0.71075 \AA$ Á) of Spring-8 (Hyogo, Japan) using Rigaku Mercury II detector. The data obtained were processed using Crystal-Clear (Rigaku) on a Pentium computer, and were corrected for Lorentz and polarization effects. The structures were solved by direct methods [51], and expanded using Fourier techniques [52]. Hydrogen atoms were refined using the riding model. The final cycle of full-matrix least-squares refinement on $F^{2}$ was based on 12,489 observed reflections and 470 variable parameters for 4; 14,053 observed reflections and 577 variable parameters for 5; 11,457 observed reflections and 507 variable parameters for 6 . Neutral atom scattering factors were taken from Cromer and Waber [53]. All calculations were performed using the Crystal Structure [54] crystallographic software package except for refinement, which was performed using SHELXL-97 [55]. Details of final refinement, as well as the bond lengths and angle, are summarized in Tables S1-S3, and the numbering scheme employed is also shown in Figures S7-S9, which were drawn with ORTEP at 50\% probability ellipsoids. CCDC numbers 1582225 (4), 1582226 (5) and 1582227 (6) contain the supplementary crystallographic data for this paper. These data can be obtained free of charge from the Cambridge Crystallographic Data Centre via www.ccdc.cam.ac.uk/data_request/cif.

\section{Conclusions}

In the present study, we found that the planar tetrapalladium cluster can be easily obtained by the reaction of cyclic tetrasilane with $\mathrm{Pd}\left(\mathrm{CN}^{t} \mathrm{Bu}\right)_{2}$. The ligand exchange of the cluster led to the formation of new clusters, with or without maintaining the core structure. These results indicate that clustering metal atoms through insertion into the $\mathrm{Si}-\mathrm{Si}$ bonds of cyclic organopolysilanes is an effective way to synthesise transition metal clusters with bridging organosilylene ligands. Efforts are underway to synthesise a series of new metal clusters by the reaction of appropriate transition metal precursors with cyclic organopolysilanes. Application of these cluster molecules as functional materials, such as catalysts, will also be investigated in the near future.

Supplementary Materials: The following are available online at www.mdpi.com/2304-6740/5/4/84/s1, CIF and cif-checked files, detailed crystallographic data, the actual NMR charts of complexes $\mathbf{4}, \mathbf{5}$ and $\mathbf{6}$, and IR chart of 4 .

Acknowledgments: This work was supported by the Core Research Evolutional Science and Technology (CREST) Program of Japan Science and Technology Agency (JST) Japan, the Cooperative Research Program of "Network Joint Research Center for Materials and Devices.", Grant in Aid for Scientific Research (B) (No. 16H04120) and Challenging Exploratory Research (No. 26620047) from the Ministry of Education, Culture, Sports, Science and Technology, Japan, the Iwatani Naoji Foundation, and the JFE 21st Century Foundation. This work was 
also supported by the special fund of Institute of Industrial Science, The University of Tokyo. The synchrotron radiation experiments were performed at the BL02B1 of SPring- 8 with the approval of the Japan Synchrotron Radiation Research Institute (JASRI) (Proposal No. 2016A1118, 2016B1392, and 2017A1400).

Author Contributions: Yusuke Sunada, Soichiro Kyushin and Hideo Nagashima conceived and designed the experiments; Yusuke Sunada, Nobuhiro Taniyama and Kento Shimamoto performed the experiments; Yusuke Sunada analyzed the data; Yusuke Sunada and Hideo Nagashima wrote the paper.

Conflicts of Interest: The authors declare no conflict of interest.

\section{References}

1. Markó, L.; Vizi-Orosz, A. Metal Clusters in Catalysis; Gates, B.C., Guczi, L., Knözinger, H., Eds.; Elsevier: Amsterdam, The Netherlands, 1986.

2. Süss-Fink, G.; Jahncke, M. Catalysis by Di- and Polynuclear Metal Cluster Complexes; Adams, R.D., Cotton, F.A., Eds.; Wiley-VCH: Toronto, ON, Canada, 1998.

3. Puddephatt, R.J. Metal Clusters in Chemistry; Braunstein, P., Oro, L.A., Raithby, P.R., Eds.; Wiley-VCH: Toronto, ON, Canada, 1999.

4. Braga, D.; Dyson, F.; Grepioni, F.; Johnson, B.F.G. Arene clusters. Chem. Rev. 1994, 94, 1585-1620. [CrossRef]

5. Inagaki, A.; Takaya, Y.; Takemori, T.; Suzuki, H.; Tanaka, M.; Haga, M. Trinuclear ruthenium complex with a face-capping benzene ligand. Hapticity change induced by two-electron redox reaction. J. Am. Chem. Soc. 1997, 119, 625-626. [CrossRef]

6. Holm, R.H.; Lo, W. Structural Conversions of synthetic and protein-bound iron-sulfur clusters. Chem. Rev. 2016, 116, 13685-13713. [CrossRef] [PubMed]

7. Groysman, S.; Holm, R.H. Biomimetic chemistry of iron, nickel, molybdenum, and tungsten in sulfur-ligated protein sites. Biochemistry 2009, 48, 2310-2320. [CrossRef] [PubMed]

8. Lee, S.C.; Lo, W.; Holm, R.H. Developments in the biomimetic chemistry of cubane-type and higher nuclearity iron-sulfur cluster. Chem. Rev. 2014, 114, 3579-3600. [CrossRef] [PubMed]

9. Ohki, Y.; Tatsumi, K. New synthetic routes to metal-sulfur clusters relevant to the nitrogenase metallo-clusters. Z. Anorg. Allg. Chem. 2013, 639, 1340-1349. [CrossRef]

10. Murahashi, T.; Kurosawa, H. Organopalladium complexes containing palladium-palladium bonds. Coord. Chem. Rev. 2002, 231, 207-228. [CrossRef]

11. Horiuchi, S.; Tachibana, Y.; Yamashita, M.; Yamamoto, K.; Masai, K.; Takase, K.; Matsutani, T.; Kawamata, S.; Kurashige, Y.; Yanai, T.; et al. Multinuclear metal-binding ability of a carotene. Nat. Commun. 2015, 6, 7742/1-7742/8. [CrossRef] [PubMed]

12. Murahashi, T.; Mochizuki, E.; Kai, Y.; Kurosawa, H. Organometallic sandwich chains made of conjugated polyenes and metal-metal chains. J. Am. Chem. Soc. 1999, 121, 10660-10661. [CrossRef]

13. Tatsumi, Y.; Nagai, T.; Nakashima, H.; Murahashi, T.; Kurosawa, H. Stepwise growth of polypalladium chains in 1,4-diphenyl-1,3-butadiene sandwich complexes. Chem. Commun. 2004, 1430-1431. [CrossRef] [PubMed]

14. Nakamae, K.; Takeemura, Y.; Kure, B.; Nakajima, T.; Kitagawa, Y.; Tanase, T. Self-alignment of low-valent octanuclear palladium atoms. Angew. Chem. Int. Ed. 2015, 54, 1016-1023. [CrossRef] [PubMed]

15. Goto, E.; Begum, R.A.; Zhan, S.; Tanase, T.; Tanigaki, K.; Sakai, K. Linear, redox-active $\mathrm{Pt}_{6}$ and $\mathrm{Pt}_{2} \mathrm{Pd}_{2} \mathrm{Pt}_{2}$ clusters. Angew. Chem. Int. Ed. 2004, 43, 5029-5032. [CrossRef] [PubMed]

16. Goto, E.; Begum, R.A.; Ueno, C.; Hosokawa, A.; Yamamoto, C.; Nakamae, K.; Liure, B.; Nakajima, T.; Kajiwara, T.; Tanase, T. Electron-deficient $\mathrm{Pt}_{2} \mathrm{M}_{2} \mathrm{Pt}_{2}$ hexanuclear metal strings $(\mathrm{M}=\mathrm{Pt}$, $\mathrm{Pd}$ ) supported by triphosphine ligands. Organometallics 2014, 33, 1893-1904. [CrossRef]

17. Takemura, Y.; Takenaka, H.; Nakajima, T.; Tanase, T. Hexa- and octagold chains from flexible tetragold molecular units supported by linear tetraphosphine ligands. Angew. Chem. Int. Ed. 2009, 48, 2157-2161. [CrossRef] [PubMed]

18. Hua, S.-A.; Cheng, M.-C.; Chen, C.-H.; Peng, S.-M. From homonuclear metal string complexes to heteronuclear metal string complexes. Eur. J. Inorg. Chem. 2015, 2015, 2510-2523. [CrossRef]

19. Hurley, T.J.; Robinson, M.A. Nickel(II)-2,2'-dipyridylamine system. I. Synthesis and stereochemistry of the complexes. Inorg. Chem. 1968, 7, 33-38. [CrossRef] 
20. Wu, L.P.; Field, P.; Morrissey, T.; Murphy, C.; Nagle, P.; Hathaway, B.; Simmons, C.; Thornton, P. Crystal structure and electronic properties of dibromo- and dichloro-tetrakis[ $\mu_{3}$-bis(2-pyridyl)amido]tricopper(II) hydrate. J. Chem. Soc. Dalton Trans. 1990, 3835-3840. [CrossRef]

21. Liu, I.P.-O.; Bénard, M.; Hasanov, H.; Chen, I.-W.P.; Tseng, W.-H.; Fu, M.-D.; Rohmer, M.-M.; Chen, C.-H.; Lee, G.-H.; Peng, S.-M. A new generation of metal string complexes: Structure, magnetism, spectroscopy, theoretical analysis, and single molecular conductance of an unusual mixed-valence linear $\left[\mathrm{Ni}_{5}\right]^{8+}$ complex. Chem. Eur. J. 2007, 13, 8667-8677. [CrossRef] [PubMed]

22. Ismayilov, R.-H.; Wang, W.-Z.; Lee, G.-H.; Yeh, C.-Y.; Hua, S.-A.; Song, Y.; Rohmer, M.-M.; Bénard, M.; Peng, S.-M. Two linear undecanickel mixed-valence complexes: Increasing the size and the scope of the electronic properties of nickel metal strings. Angew. Chem. Int. Ed. 2011, 50, 2045-2048. [CrossRef] [PubMed]

23. Murahashi, T.; Fujimoto, M.; Oka, M.; Hashimoto, Y.; Uemura, T.; Tatsumi, Y.; Nakao, Y.; Ikeda, A.; Sakaki, S.; Kurosawa, H. Discrete sandwich compounds of monolayer palladium sheets. Science 2006, 313, 1104-1107. [CrossRef] [PubMed]

24. Murahashi, T.; Inoue, R.; Usui, K.; Ogoshi, S. Square tetrapalladium sheet sandwich complexes: Cyclononatetraenyl as a versatile face-capping ligand. J. Am. Chem. Soc. 2009, 131, 9888-9889. [CrossRef] [PubMed]

25. Murahashi, T.; Usui, K.; Inoue, R.; Ogoshi, S.; Kurosawa, H. Metallocenoids of platinum: Syntheses and structures of triangular triplatinum sandwich complexes of cycloheptatrienyl. Chem. Sci. 2011, 2, 117-122. [CrossRef]

26. Murahashi, T.; Kato, N.; Uemura, T.; Kurosawa, H. Rearrangement of a $\mathrm{Pd}_{4}$ skeleton from a $1 \mathrm{D}$ Chain to a $2 \mathrm{D}$ sheet on the face of a perylene or fluoranthene ligand caused by exchange of the binder molecule. Angew. Chem. Int. Ed. 2007, 46, 3509-3512. [CrossRef] [PubMed]

27. Ishikawa, Y.; Kimura, S.; Yamamoto, K.; Murahashi, T. Bridging coordination of vinylarenes to $\mathrm{Pd}_{3}-$ or $\mathrm{Pd}_{4}$ cluster sites. Chem. Eur. J. 2017, 23, 14149-14152. [CrossRef] [PubMed]

28. Murahashi, T.; Uemura, T.; Kurosawa, H. Perylene-Tetrapalladium sandwich complexes. J. Am. Chem. Soc. 2003, 125, 8436-8437. [CrossRef] [PubMed]

29. Sunada, Y.; Haige, R.; Otsuka, K.; Kyushin, S.; Nagashima, H. A ladder polysilane as a template for folding palladium nanosheets. Nat. Commun. 2013, 4, 3014/1-3014/7. [CrossRef] [PubMed]

30. Suginome, M.; Kato, Y.; Takeda, N.; Oike, H.; Ito, Y. Reactions of a spiro trisilane with palladium complexes: synthesis and structure of Tris(organosilyl) $\mathrm{CpPd}^{\mathrm{IV}}$ and Bis(organosilyl)( $\mu$-organosilylene) $\mathrm{Pd}_{2}{ }_{2}$ complexes. Organometallics 1998, 17, 495-497. [CrossRef]

31. Ansell, M.B.; Navarro, O.; Spencer, J. Transition metal catalyzed element-element' additions to alkynes. Coord. Chem. Rev. 2017, 336, 54-77. [CrossRef]

32. Ansell, M.B.; Roberts, D.E.; Cloke, F.G.N.; Navarro, O.; Spencer, J. Synthesis of an $\left[(\mathrm{NHC})_{2} \mathrm{Pd}\left(\mathrm{SiMe}_{3}\right)_{2}\right]$ complex and catalytic cis-bis(silyl)ations of alkynes with unactivated disilanes. Angew. Chem. Int. Ed. 2015, 54, 5578-5582. [CrossRef] [PubMed]

33. Suginome, M.; Oike, H.; Park, S.-S.; Ito, Y. Reactions of Si-Si $\sigma$-bonds with Bis( $t$-alkyl isocyanide)palladium(0) complexes, synthesis and reactions of cyclic Bis(organosilyl)palladium complexes. Bull. Chem. Soc. Jpn. 1996, 69, 289-299. [CrossRef]

34. Chen, Y.; Sunada, Y.; Nagashima, H.; Sakaki, S. Theoretical study of $\mathrm{Pd}_{11} \mathrm{Si}_{6}$ nanosheet compounds including seven-coordinated Si species and its Ge analogues. Chem. Eur. J. 2016, 22, 1076-1087. [CrossRef] [PubMed]

35. Yamada, T.; Mawatari, A.; Tanabe, M.; Osakada, K.; Tanase, T. Planar tetranuclear and dumbbell-shaped octanuclear palladium complexes with bridging silylene ligands. Angew. Chem. Int. Ed. 2009, 48, 568-571. [CrossRef] [PubMed]

36. Tanabe, M.; Yumoto, R.; Yamada, T.; Fukuta, T.; Hoshino, T.; Osakada, K.; Tanase, T. Planar PtPd 3 complexes stabilized by three bridging silylene ligands. Chem. Eur. J. 2017, 23, 1386-1392. [CrossRef] [PubMed]

37. Shimada, S.; Li, Y.-H.; Choe, Y.-K.; Tanaka, M.; Bao, M.; Uchimaru, T. Multinuclear palladium compounds containing palladium centers ligated by five silicon atoms. Proc. Nat. Acad. Sci. USA 2007, 104, 7758-7763. [CrossRef] [PubMed]

38. Tanabe, M.; Ishikawa, N.; Chiba, M.; Ide, T.; Osakada, K.; Tanase, T. Tetrapalladium complex with bridging germylene ligands. Structural change of the planar $\mathrm{Pd}_{4} \mathrm{Ge}_{3}$ core. J. Am. Chem. Soc. 2011, 133, 18598-18601. [CrossRef] [PubMed] 
39. Beck, R.; Johnson, S.A. Structural similarities in dinuclear, tetranuclear, and pentanuclear nickel silyl and silylene complexes obtained via Si-H and Si-C activation. Organometallics 2012, 31, 3599-3609. [CrossRef]

40. Bradford, A.M.; Kristof, E.; Rashidi, M.; Yang, D.-S.; Payne, N.C.; Puddephatt, R.J. Isocyanide and diisocyanide complexes of a triplatinum cluster: Fluxionality, isomerism, structure, and bonding. Inorg. Chem. 1994, 33, 2355-2363. [CrossRef]

41. Mann, B.E. Mechanism of the low-energy fluxional process in $\left[\mathrm{Fe}_{3}(\mathrm{CO})_{12-n} \mathrm{~L}_{n}\right](n=0-2)$ : A perspective. J. Chem. Soc. Dalton Trans. 1997, 1457-1471. [CrossRef]

42. Corey, J.Y. Reactions of hydrosilanes with transition metal complexes. Chem. Rev. 2016, 116, 11291-11435. [CrossRef] [PubMed]

43. Corey, J.Y. Reactions of hydrosilanes with transition metal complexes and characterization of the products. Chem. Rev. 2011, 111, 863-1071. [CrossRef] [PubMed]

44. Ogino, H.; Tobita, H. Bridged silylene and germylene complexes. Adv. Organomet. Chem. 1998, 42, $223-290$. [CrossRef]

45. Tanaka, K.; Kamono, M.; Tanabe, M.; Osakada, K. Ring expansion of cyclic triplatinum(0) silylene complexes induced by insertion of alkyne into a Si-Pt bond. Organometallics 2015, 34, 2985-2990. [CrossRef]

46. Braddock-Wilking, J.; Corey, J.Y.; Dill, K.; Rath, N.P. Formation and X-ray crystal structure determination of the novel triplatinum cluster $\left[\left(\mathrm{Ph}_{3} \mathrm{P}\right) \mathrm{Pt}\left(\mu-\mathrm{SiC}_{12} \mathrm{H}_{8}\right)\right]_{3}$ from reaction of silafluorene with $\left(\mathrm{Ph}_{3} \mathrm{P}\right)_{2} \mathrm{Pt}\left(\eta^{2}-\mathrm{C}_{2} \mathrm{H}_{4}\right)$. Organometallics 2002, 21, 5467-5469. [CrossRef]

47. Osakada, K.; Tanabe, M.; Tanase, T. A triangular triplatinum complex with electron-releasing $\mathrm{SiPh}_{2}$ and $\mathrm{PMe}_{3}$ ligands: $\left[\left\{\mathrm{Pt}\left(\mu-\mathrm{SiPh}_{2}\right)\left(\mathrm{PMe}_{3}\right)\right\}_{3}\right]$. Angew. Chem. Int. Ed. 2000, 39, 4053-4055. [CrossRef]

48. Braddock-Wilking, J.; Corey, J.Y.; French, L.M.; Choi, E.; Speedie, V.J.; Rutheeford, M.F.; Yao, S.; Xu, H.; Rath, N.P. Si-H bond activation by $\left(\mathrm{Ph}_{3} \mathrm{P}\right)_{2} \mathrm{Pt}\left(\eta^{2}-\mathrm{C}_{2} \mathrm{H}_{4}\right)$ in dihydrosilicon tricycles that also contain $\mathrm{O}$ and $\mathrm{N}$ heteroatoms. Organometallics 2006, 25, 3974-3988. [CrossRef]

49. Watanebe, H.; Muraoka, T.; Kageyama, M.; Yoshizumi, K.; Nagai, Y. Synthesis and some spectral properties of peralkylcyclopolysilanes, [ $\left.\mathrm{R}^{1} \mathrm{R}^{2} \mathrm{Si}\right]_{n}(n=4-7)$. Organometallics 1984, 3, 141-147. [CrossRef]

50. Ryan, S.J.; Schimler, S.D.; Bland, D.C.; Sanford, M.S. Acyl azolium fluorides for room temperature nucleophilic aromatic fluorination of chloro- and nitroarenes. Org. Lett. 2015, 17, 1866-1869. [CrossRef] [PubMed]

51. Burla, M.C.; Caliandro, R.; Camalli, M.; Carrozzini, B.; Cascarano, G.L.; Giacovazzo, C.; Mallamo, M.; Mazzone, A.; Polidori, G.; Spagna, R. SIR2011: A new package for crystal structure determination and refinement. J. Appl. Cryst. 2012, 45, 357-361. [CrossRef]

52. Beurskens, P.T.; Admiraal, G.; Beurskens, G.; Bosman, W.P.; de Gelder, R.; Israel, R.; Smits, J.M.M. The DIRDIF-99 program system; Technical Report of the Crystallography Laboratory; University of Nijmegen: Nijmegen, The Netherlands, 1999.

53. Cromer, D.T.; Waber, J.T. International Tables for X-ray Crystallography; Kynoch Press: Birmingham, UK, 1974.

54. CrystalStructure 4.0, Crystal Structure Analysis Package; Rigaku Corporation: Tokyo, Japan, 2000-2010.

55. Sheldrick, G.M. A short history of SHELX. Acta Cryst. 2008, A64, 112-122. [CrossRef] [PubMed]

(c) 2017 by the authors. Licensee MDPI, Basel, Switzerland. This article is an open access article distributed under the terms and conditions of the Creative Commons Attribution (CC BY) license (http:/ / creativecommons.org/licenses/by/4.0/). 